\title{
FARMER SURVEY OF YELLOW DWARF VIRUSES IN AUTUMN-SOWN CEREALS IN CANTERBURY
}

\author{
G. GREER ${ }^{1}$ and D.A.J. TEULON ${ }^{2}$ \\ ${ }^{1}$ Agribusiness and Economics Research Unit, Lincoln University, Canterbury, \\ New Zealand \\ ${ }^{2}$ Crop \& Food Research, Private Bag 4704, Christchurch, New Zealand
}

Corresponding author: teulond@crop.cri.nz

\begin{abstract}
A postal survey of 700 Canterbury arable farmers was undertaken during August/September 1998 to ascertain the importance of yellow dwarf viruses (YDV) in autumn sown cereal crops. The survey also sought to document farmers' practices for YDV management and the use to which they put the aphid monitoring and virus forecasting system provided by Crop \& Food Research as well as their opinions on its effectiveness. The response rate was $24 \%$. Most farmers had experienced YDV although for many it was not a recent problem. Many farmers employed more than one strategy for YDV management, the most common being to sow late or apply preventative insecticides to control aphid vectors of these viruses. The monitoring information had been seen by over $80 \%$ of respondents, and was judged as a good or satisfactory use of levy funds by over $92 \%$. Information from the aphid monitoring virus forecasting system was used as an aid in the decision making process for YDV management.
\end{abstract}

Keywords: farmer survey, yellow dwarf virus, aphid monitoring, virus forecasting, autumn-sown cereals.

\section{INTRODUCTION}

Barley, wheat and oats are the major cereal crops in New Zealand, with the greatest proportion of these crops grown in Canterbury. All these cereals are susceptible to yellow dwarf viruses (YDV) (barley yellow dwarf and cereal yellow dwarf) (Mayo \& D'Arcy 1999), which are a major source of cereal crop loss in New Zealand (Teulon et al. 1999a). Yellow dwarf viruses impose an estimated cost of $\$ 3.7$ million per year in Canterbury (Bicknell \& Greer 1999). Yellow dwarf viruses are transmitted by at least six aphid species in New Zealand (Farrell \& Stufkens 1992; Teulon et al. 1999b). There are distinct flight peaks in Canterbury in spring and autumn, and periods of low aphid flight activity during mid-winter and mid-summer (Farrell \& Stufkens 1989).

The incidence of YDV in autumn-sown cereals varies between years, and is influenced by a number of factors including the timing and size of aphid flights as well as sowing dates and pest management practices. Lowe (1967) recommended that winter wheat should be sown after 1 June to avoid infection by late-autumn flights of the aphid vectors, and Farrell \& Stufkens (1992) concluded that the late sowing of cereal crops in Canterbury (after 15 May) contributed to low levels of YDV infection in most years between 1983 and 1991. Knowledge of aphid flight activity after crop emergence can be used to decide on the need for insecticide spray applications to control vectors and to reduce YDV infections in crops (Farrell \& Stufkens 1989; Teulon et al. 1999a).

Over the last 20 years Crop \& Food Research staff have sampled aphids in a $7.5 \mathrm{~m}$ high suction trap at Lincoln, Canterbury, during autumn and winter. A significant relationship between numbers of aphids trapped in June and July and the proportion of crops with levels of YDV was established by Farrell \& Stufkens (1992). In general, this relationship has continued to hold with warmer winters probably contributing to greater virus incidence in recent years (Teulon et al. 1999a; 2001). A successful application, 
co-ordinated by the Foundation for Arable Research (FAR) in association with Crop \& Food Research, was made by a farmers' group (Canterbury Arable Research Groups) to the Agricultural and Marketing Research and Development Trust (AGMARDT) to fund an expanded aphid monitoring-virus forecasting programme for three years (1998-2000). One of the objectives of this programme, and the focus of this paper, was to survey growers to ascertain their perceived importance of YDV in autumn-sown cereal crops, current practices for YDV management and the farmers use and opinions of the aphid monitoring and virus forecasting system.

\section{METHODS}

A postal survey was sent to Canterbury arable farmers during August/September 1998. The survey, and a letter explaining the purpose of the survey, was posted to a random sample of 700 farmers from FAR's mailing list. The Privacy Act precluded the identification of farmers so it was not possible to send reminder letters. Rather reminders to complete and return the questionnaires were published in several Canterbury newspapers (The Press, Ashburton Guardian and Timaru Herald) in late September 1998. The data obtained from the survey were analysed using SPSSPC (Statistics for Social Scientists).

\section{General}

\section{RESULTS}

There were 169 valid responses to the survey, giving a $24 \%$ response rate. Published reminders resulted in few additional responses. The population of arable farmers in Canterbury is believed to be between 1800 and 1900 so estimates based on this sample size have an expected maximum error of $7.0 \%$. This and other surveys (G. Greer, unpubl. data) suggest that arable growers are reluctant participants in postal surveys.

The largest group of responses was from the Ashburton District (49.7\%), followed by Selwyn $(25.8 \%)$, Timaru $(11.7 \%)$ and Waimate $(11.0 \%)$. Farmers for whom cropping income comprised $75 \%$ or more of gross farm income were the largest group of respondents $(46.1 \%$ ), followed by those for whom cropping comprised $50-74 \%$ of income $(21.6 \%), 25-49 \%(20.4 \%)$ and below $25 \%(12.0 \%)$. The total area farmed by respondents was 40,029 ha. The largest group of responses was from farms of more than 300 ha (30.9\%) with responses from other farmed areas being: 50 ha, 5.6\%; 50-99 ha, 5.6\%; 100-149 ha, $11.7 \%$; 150-199 ha, $13.6 \% ; 200-249$ ha, $22.2 \%$ and $250-299$ ha, $10.5 \%$.

In total, $69 \%$ of respondents sowed at least some autumn cereal crops, with the total area of autumn crops sown by all respondents being 5162 ha. Wheat comprised $90.5 \%$ of the total area sown in autumn by respondents, barley $5.8 \%$ and oats $3.7 \%$. Springsown crops consisted of wheat (2097 ha), barley (3651 ha) and oats (265 ha). The largest group $(47 \%)$ of those who grow autumn crops sow all autumn cereals after mid-May, while $21 \%$ sow all cereals before mid-May. The average proportion of late-sown autumn crops was $65 \%$ by area.

\section{Experience of yellow dwarf virus and aphids}

The majority of those surveyed $(67.4 \%)$ believed that they had experienced YDV in cereal crops at some time, while only $16.6 \%$ were sure they had not. Sixteen percent did not know whether their crops had been infected or not. Amongst those who had experienced the disease, members of the largest group (44\%) were unable to recall the last growing season in which they had a significant problem and the second largest group (17.4\%) thought it to be before 1990 . Between 8.7 and $12.2 \%$ of respondents experienced YDV in the 3 years before the survey (1995, 1996 and 1997). In a separate telephone survey several growers acknowledged that YDV could be highly significant in the event of a severe outbreak (Bicknell \& Greer 1999).

\section{Yellow dwarf virus management}

Table 1 indicates the strategies for YDV management in relation to the number of respondents and to the total area of cereals grown. No measures were taken to manage YDV by $11.1 \%$ of those who grew autumn crops including $8 \%$ of those who had 
experienced YDV in the past. The proportion of the area that was not protected was $6.7 \%$. The most commonly used prevention strategies were to sow late (48\% of respondents, applied to $31 \%$ of area) or apply preventative sprays (19.7\% of respondents, applied to $33 \%$ of area). However, not all of those who sowed at least part of their autumn cereal crop after mid-May considered this to be a means of preventing YDV. The proportion of respondents using the Crop \& Food Research forecast for YDV management was $16.2 \%$; this related to $29.4 \%$ of the total autumn-sown cereal area. Many farmers used more than one measure for YDV management.

TABLE 1: Yellow dwarf virus management strategies in autumn-sown cereal crops. More than one strategy was used by a number of respondents.

\begin{tabular}{lcc}
\hline Strategy & \% of respondents & \% of area \\
\hline No measure & 11.1 & 6.7 \\
Sowing after mid-May & 48.7 & 31.3 \\
Prophylactic spray each season & 19.7 & 33.2 \\
Respond to Crop \& Food Research forecast & 16.2 & 29.4 \\
Monitor self \& spray when aphid numbers are high & 29.1 & 26.5 \\
Insecticide seed treatment & 19.7 & 15.7 \\
Resistant varieties & 2.1 & 0.0 \\
Other & 9.4 & 2.6 \\
\hline
\end{tabular}

While differences were observed in the proportions of respondents applying protectant insecticides for aphid control in different districts (Selwyn $-36 \%$, Timaru $-21 \%$, Ashburton $-15 \%$ and Waimate $-11 \%$ ), the differences were not statistically significant. However, there was a significant difference $(\mathrm{P}<0.05)$ in the extent of protectant spraying between those who had experienced YDV $(21 \%)$ and those who either had not experienced the disease or did not know whether they had experienced the disease $(9 \%)$.

Of the respondents who had sprayed autumn-sown crops for aphid control at any time in the past (31.8\%), 78\% of those who had sprayed early-sown crops sprayed the whole crop area, while only $58 \%$ of those who had sprayed late-sown crops sprayed the whole crop area. Twenty-four percent of those planting late treated between 20 and $29 \%$ of the late-sown area.

\section{Insecticide use}

A range of insecticides was used by respondents for aphid control (Table 2), with pirimicarb being used by the highest proportion, followed by lambda cyhalothrin and esfenvalerate. The majority of respondents reported using only one application (average: 1.1). Aphicides were generally applied in conjunction with other sprays $(80 \%)$ and by the farmer or farm labour $(71 \%)$ rather than a contractor.

TABLE 2: Insecticides most recently used for aphid/YDV management in autumn-sown cereals in 1998.

\begin{tabular}{llccc}
\hline Insecticide & Insecticide group & $\%$ & $\begin{array}{c}\text { Registered } \\
\text { in 1998 }\end{array}$ & $\begin{array}{c}\text { Registered } \\
\text { in 2002 }\end{array}$ \\
\hline Pirimicarb & carbamate & 23.2 & yes & yes \\
Lambda cyhalothrin & synthetic pyrethroid & 16.1 & no & no \\
Esfenvalerate & synthetic pyrethroid & 14.2 & no & no \\
Dimethoate & organophosphate & 12.7 & yes & yes \\
Demeton-S-methyl & organophosphate & 10.7 & yes & no \\
Chlorpyrifos & organophosphate & 8.9 & yes & yes \\
Taufluvalinate & synthetic pyrethroid & 7.1 & no & no \\
Other & & 17.1 & & \\
\hline
\end{tabular}




\section{Aphid monitoring and virus forecasting service}

Most of the farmers surveyed (83.7\% of all respondents, $89 \%$ who grow autumn cereals, $92 \%$ who sow autumn cereals early) had recently seen or obtained the information published in a range of media by Crop \& Food Research and FAR. Most had seen or obtained the information from more than one source but mostly from grower information sent out by FAR or the major Canterbury regional newspaper, The Press (Table 3). Twenty percent had obtained the information by word of mouth, which suggests that the monitoring service was gaining a reasonably high profile in the sector.

\section{TABLE 3: Farmer sources of information about the Crop \& Food Research aphid monitoring and virus forecast.}

\begin{tabular}{lc}
\hline Source & $\%$ \\
\hline Grower information sent by FAR & 74.1 \\
'The Press' - regional newspaper & 56.8 \\
'Ashburton Guardian' - local newspaper & 27.3 \\
'Timaru Herald' - local newspaper & 24.5 \\
Word of mouth & 20.1 \\
Other print media & 10.8 \\
Internet (www.AphidWatch.com) & 7.2 \\
Phone service & 6.4 \\
Other & 5.2 \\
\hline
\end{tabular}

In total, $50 \%$ of survey respondents who were aware of the information (54.5\% of those who plant autumn crops and $62 \%$ of those who plant autumn crops before mid-May) said that they had used the service when making decisions, although only a relatively small proportion had reported spraying in response to the forecast. In separate telephone interviews, farmers indicated that they used the trapping information and forecasts to alert them to the need to intensify their own monitoring for aphids rather than indicate that they should definitely apply insecticides (Bicknell \& Greer 1999). Another 30.4\% (late-sown) and $32.1 \%$ (early-sown) indicated that they would use the monitoring information when making decisions in the future. Amongst those who had seen the information but had not used it (19.2\% for late-sown, $5.7 \%$ for early-sown), only $16.4 \%$ were taking no measures to prevent the disease. Most (59\%) planted after mid-May.

When respondents were asked how they rated the provision of this service to the industry as a use of Arable Commodities Levy money, 45.4\% considered it a good use, $47.2 \%$ considered it a satisfactory use and only $7.4 \%$ considered it an unsatisfactory use.

\section{DISCUSSION}

Despite the potential for YDV to contribute to significant economic losses (Bicknell \& Greer 1999), our survey suggested that there was a low awareness of YDV in cereal crops. Although most farmers believed that they had experienced the disease in their crops, many were rather vague as to when this had occurred. Low awareness may have been due to the imprecise visual symptoms of these viruses (D'Arcy 1995) and the fact that many farmers sowed after mid-May, which would lower the likelihood of virus infection. A trend to plant early (from early April onwards), which exposes young crops to periods of high aphid flight activity, and a number of warm winters (Teulon et al. 1999a, 2001) have both probably contributed to increased virus incidence in autumnsown crops and farmer awareness of YDV in recent years.

Early sowing of autumn cereal crops necessitates greater reliance on the use of insecticides applied to the seed prior to sowing, at sowing or as foliar sprays. We expect the current use of seed treatments and the number of foliar insecticide applications to increase over those reported at the time of this survey. There is also likely to be greater use of insecticides with a longer residue life (e.g. synthetic pyrethroids) than those with 
a short residue life (e.g. pirimicarb). Many of the insecticides reported as foliar applications were not registered for aphid control on cereals in New Zealand at the time of the survey.

A greater proportion of farmers who sowed early said they used the aphid-monitoring and virus forecasting service compared with farmers who sowed late. This probably reflects the greater potential impact of virus in early-sown crops compared to late-sown crops. Nevertheless, knowledge of aphid flight activity can be important for late-sown cereals. This was the case in 1999 when large aphid flights continued into June with resultant virus infection on unprotected crops (D.A.J. Teulon, unpubl. data). The YDV prediction service was clearly seen to be worthwhile as $93 \%$ of respondents considered it to be a good or satisfactory use of Arable Commodities Levy money.

The main source of aphid flight information for farmers was indirectly through FAR. It is likely that use of this source has increased in recent years with an upgraded email service developed by FAR (FAR Crop Action). The Crop \& Food Research direct dial phone service is no longer in use and it remains to be seen whether the dedicated website (AphidWatch.com) will grow in usefulness as farmers become more familiar with the internet.

\section{ACKNOWLEDGEMENTS}

We thank the 169 unnamed respondents of the survey. This work was funded by FAR, AGMARDT and the New Zealand Foundation for Research, Science and Technology.

\section{REFERENCES}

Bicknell, K.; Greer, G. 1999: The value of the Crop \& Food Research BYDV forecast to Canterbury arable farmers. Agribusiness and Economics Research Unit, Lincoln University, Canterbury, New Zealand.

D’Arcy, C.J. 1995: Symptomology and host range of barley yellow dwarf. In: D'Arcy, C.J.; Burnett, P.A. ed. Barley yellow dwarf 40 years of progress. APS Press, St Paul, Minnesota. Pp. 9-28.

Farrell, J.A.; Stufkens, M.A.W. 1989: Flight activity and cereal host relationships of Rhopalosiphum spp. in Canterbury. N.Z. J. Crop Hort. Sci. 17: 1-7.

Farrell, J.A.; Stufkens, M.A.W. 1992: Cereal aphid flights and barley yellow dwarf virus infection of cereals in Canterbury, New Zealand. N.Z. J. Crop Hort. Sci. 20: 407-412.

Lowe, A.D. 1967: Sowing date as an aphid-virus control technique. Proc. $20^{\text {th }}$ N.Z. Weed and Pest Control Conf.: 214-216.

Mayo, M.A.; D’Arcy, C.J. 1999: Family Luteoviridae: a reclassification of Luteoviruses. In: Smith, H.C.; Barker, H. ed. The Luteoviridae. CABI Publishing, Walingford, UK. Pp. 15-22.

Teulon, D.A.J.; Stufkens, M.A.W.; Nicol, D.; Harcourt, S.J. 1999a: Forecasting barley yellow dwarf virus in autumn-sown cereals in 1998. Proc. 52nd N.Z. Plant Prot. Conf.: 187-191.

Teulon, D.A.J.; Nicol, D.; Stufkens, M.A.W. 1999b: Apple grass aphid (Rhopalosiphum insertum) on cereals in Canterbury. Proc. 52nd N.Z. Plant Prot. Conf.: 192-198.

Teulon, D.A.J.; Fletcher, J.D.; Cromey, M.G. 2001: Localised severe incidence of barley yellow dwarf virus in winter wheat. N.Z. Plant Prot. 54: 253. 